\title{
Fixed Lymph Node
}

National Cancer Institute

\section{Source}

National Cancer Institute. Fixed Lymph Node. NCI Thesaurus. Code C161610.

A lymph node that has reduced mobility or is attached to adjacent structures. 